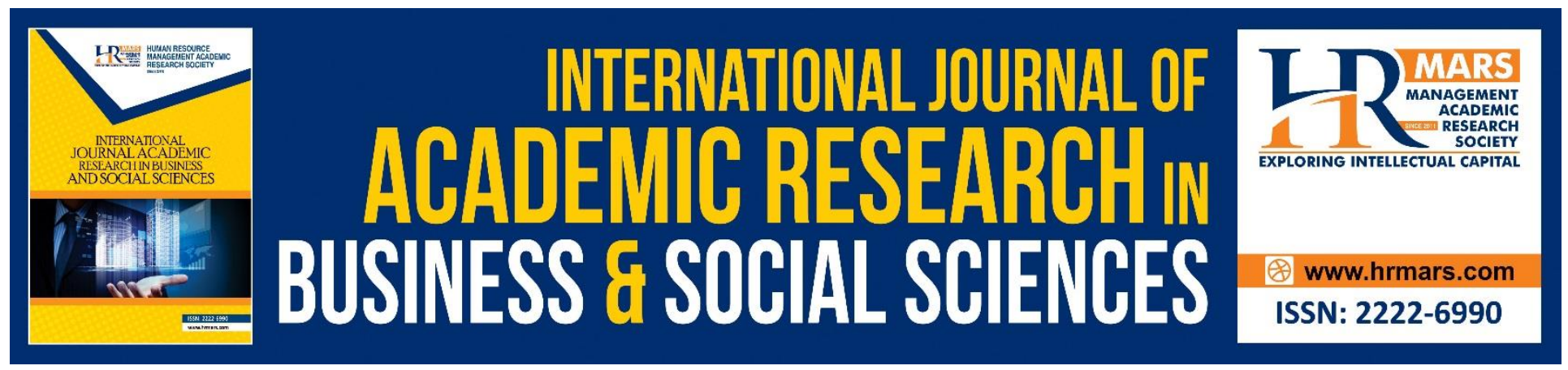

\title{
Non-performing loans and its implications toward Bank Performance: Comparison on Islamic and Conventional Banks
}

Eni Noreni Binti Mohamad Zain and Puspa Liza Binti Ghazali

To Link this Article: http://dx.doi.org/10.6007/IJARBSS/v8-i12/5052

DOI: $10.6007 /$ IJARBSS/v8-i12/5052

Received: 17 Oct 2018, Revised: 30 Nov 2018, Accepted: 19 Dec 2018

Published Online: 28 Dec 2018

In-Text Citation: (Zain \& Ghazali, 2018)

To Cite this Article: Zain, E. N. B. M., \& Ghazali, P. L. B. (2018). Non-performing loans and its implications toward Bank Performance: Comparison on Islamic and Conventional Banks. International Journal of Academic Research in Business and Social Sciences, 8(12), 528-537.

Copyright: (C) 2018 The Author(s)

Published by Human Resource Management Academic Research Society (www.hrmars.com)

This article is published under the Creative Commons Attribution (CC BY 4.0) license. Anyone may reproduce, distribute, translate and create derivative works of this article (for both commercial and non-commercial purposes), subject to full attribution to the original publication and authors. The full terms of this license may be seen at: http://creativecommons.org/licences/by/4.0/legalcode

Vol. 8, No. 12, 2018, Pg. 528 - 537

http://hrmars.com/index.php/pages/detail/IJARBSS

JOURNAL HOMEPAGE

Full Terms \& Conditions of access and use can be found at http://hrmars.com/index.php/pages/detail/publication-ethics 


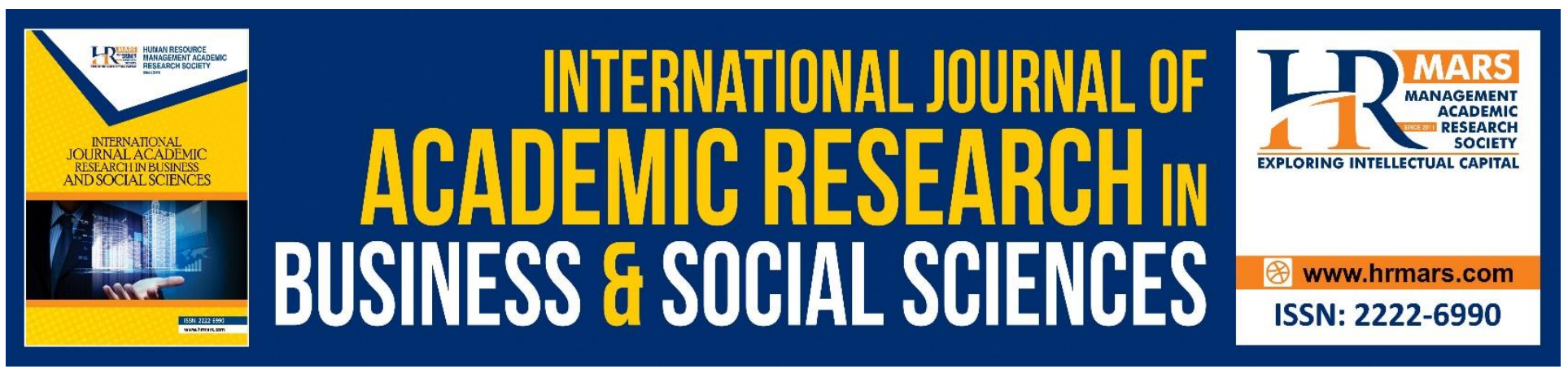

\title{
Non-performing loans and its implications toward Bank Performance: Comparison on Islamic and Conventional Banks
}

\author{
${ }^{1}$ Eni Noreni Binti Mohamad Zain and ${ }^{2}$ Puspa Liza Binti Ghazali \\ $1 \& 2$ Faculty of Economic and Management Sciences, Universiti Sultan Zainal \\ Abidin, 21300 Kuala Nerus, Malaysia
}

\begin{abstract}
Non-performing loans (NPLS) could be one of the main reasons toward economic and financial instability in the most of the countries in this world. Therefore, this study attempts to discuss the factors that lead to the NPL and hence to see the implications toward bank performance. Many previous studies have solely focused on investigating the determinants of non-performing loans (NPLs) for conventional banks and it seems like there are lack of research were done for Islamic banks industries. According to the past studies, there are two main categories of the factors, which are macroeconomics factors, and bank-specific factors were mentioned as the major determinants of NPLs. By looking at both financial sectors which conventional and Islamic banking sectors, the implications of the NPLs will be find out and thus it aimed to model non-performing loans in a few Asian countries and later do a comparison across the model.
\end{abstract}

Keywords: Non-performing loans, bank performance, Islamic banks, conventional banks, macroeconomics, bank-specific

\section{INTRODUCTION}

The competitiveness of the banking sector is under great pressure to perform well in the current global banking environment, since each bank has to compete with each other locally and internationally. Therefore, Islamic banks not only compete among themselves, but also compete with conventional banks and other non-bank financial institutions. Both conventional and Islamic banks need to satisfy their stakeholders and to ensure their profitability.

The non-performing loans (NPLs) problem frequently acknowledged as one of the potential hazard that may cause globally economic and financial disequilibrium (Onsarigo, Selvan, Ramkumar and Karpagam, 2013). During the crises in late 1990s, NPLs took some banks in Asia to the failure. According to the Financial Stability Institute, addressing the problems of NPLs is a unceasing challenge. Aziz, Ibrahim and Isa (2009) acknowledged that Andrew Crockett (2003) argues that at the 
beginning NPLs may not seem in a serious manner to give a negative impact as long as banks remain liquid, and depositors retain their confidence in the system. Over time, however, if the banks are allowed to accrue interest on their NPLs the size of the problem were keep growing.

Non-performing loans (NPLS) were referring to those finance assets which the banks are no longer receive either interest or installment payments as scheduled (Lata, R.S, 2014). It is widely known that higher percentage of NPLs is often associated with the bank failures as well as developed countries. In fact, there is abundant evidence that the financial/banking crises in East Asia and SubSaharan African countries were preceded by high NPLs (Khemraj, T. \& Pasha, S., 2009).

Most of the ASEAN have faced financial problems after the subprime crisis on 2008 due to borrowers being approved for loans they could not afford. Therefore, this study will help to facilitate the managers about the cause of non-performing loans via knowing the fact through the bank specifics factors and macroeconomics factors that affecting NPLs in ASEAN countries. The purpose of this study is to examine the determinant factors of NPLs in the banking sectors and its implication on banking performance in ASEAN countries. Most of the previous literature, most of the studies on NPLs were carried out based on conventional banking systems (Zurairah Isahak, 2010). Therefore, further research will be carried out in both conventional and Islamic banking systems for comparison purposes.

\section{LITERATURE REVIEW}

\section{Loan and Financing}

Loan represents 60 percent of most commercial banks' total assets, therefore lending is the principle business activity for most conventional banks (Federal Reserve, 2007). Conversely, Islamic banks are illegal in providing loans with interest. Therefore, the financing activities become the key function of Islamic banks. All the financing operations are based on principle allowed by Shariah (Haron, S., and Shanmugam, B., 1997).

\section{NPLs and NPF}

The 90 days period is the most broadly used practice in other countries to define whether a loan or financing is non-performing. However, the description of NPL and NPF may contrast according to the types of underlying contracts.

As a general rule, impaired loans and credit facilities should be categorized in the following manner as shown in Table 1.

Table 1: Problem Loans Classifications

\begin{tabular}{|l|l|}
\hline \multicolumn{1}{|c|}{ Period of Default } & \multicolumn{1}{c|}{ Classification } \\
\hline 6 months* but less than 9 months & $\begin{array}{l}\text { Substandard, unless there is verification to } \\
\text { support a worse-off classification }\end{array}$ \\
\hline 9 months but less than 12 months & $\begin{array}{l}\text { Doubtful, unless there is verification to support } \\
\text { a worse-off classification }\end{array}$ \\
\hline 12 months and above & Bad \\
\hline
\end{tabular}

* 3 months in the case of credit cards and trade financing instruments

Source: Bank Negara Malaysia (2005) 


\section{Bank specific determinants of NPLs}

Previous studies have discovered information on variation in NPLs. Most of the studies found that the higher or larger the bank size the higher the probability of defaulting (such as Sheefeni, 2015; Gelette, 2012; Misra and Dhal, 2010; Delis and Papanikolaou, 2009; Khemraj and Pasha, 2009) .While other studies found a negative relation between bank size and NPLs. Their study argued that bigger size of the banks seems to have fewer loan defaults (Hu, Yang and Yung-Ho, 2006; Rajan and Dhal; 2003; Salas and Saurina, 2002). The negative sign of the bank size might be because of the less concentrated portfolio since bigger size of the banks allows for diversification opportunities. Thus, the results on the size of the banks are inconclusive discovered by the previous studies. Moreover, most of the previous studies were carried out based on the conventional banking system. That being so, this study will focused on Islamic and conventional banking system.

Most of the previous studies found that the capitalization is one of the factors that influencing NPLs. Numerous of the research has discovered that when the capitalization of the bank is decreasing, therefore NPLs is increasing. Hence, there is a negative relationship between capitalization and NPLs (Hasna Chaibi, 2016; Salas and Saurina, 2002; Berger and DeYoung, 1997). However, some studies shows the opposite findings which means that highly capitalized banks are likely to have high NPLs compared to their fellow with lower capitalization (Laryea, Ntow-Gyamfi and Alu, 2016; Agoraki, 2011; Boudriga, 2009). Meanwhile, the finding from Fajar and Umanto (2017) stated that there is no significance relationship between capitalization and NPLs and it is supported by the the study from Louzis (2012) and Khemraj and Pasha (2009). Most of the empirical study that has been done, the result were focusing on conventional banking system. Thus far, this study will emphasizes more on the effect of capitalization on NPLs focusing on Islamic and conventional banking system.

Many scholars hold the view that decreasing in measuring cost efficiency lead to an increase in future NPLs (Abid, Ouertani and Zouari, 2014; Belaid, 2014; Louzis, 2012; Podpiera and Weill, 2008; Berger and DeYoung, 1997; Kwan and Eisenbis, 1997; Peristiani, 1997). According to Anthanasoglou, Brissimis and Delis (2008) efficient cost managemnet is an important determinants of bank performance. Therefore, ineficient cost management may cause an increase in future NPLs. The cost efficiency usually measured by the ratio of total operating expenses to total income. So far the previous study mostly has focused on conventional banking system. The following study will discuss more on Islamic and conventional banking system.

\section{Macroeconomics Determinants of NPLs}

There is a large number of published studies on the association between GDP growth rate and NPLS. Several number of empirical studies have found that there is a negative relation between real GDP growth rate and NPLs (Mwega, 2011; Khemraj and Pasha, 2009; Jimenez and Saurina, 2006, Fofack, 2005, Salas and Saurina, 2002). They had mentioned that the higher positive level of real GDP growth typically requires a higher income. Therefore, the borrowers had their capacity to pay their debts. Consequently, it will reduced the possibility of the loan default. However, there is an inconsistency with this argument when Beck, Jakubik and Piloiu (2013) found that GDP growth rate have a positive significance effect to NPLs. This finding were supported by the previous studies that has been done by Thiagarajan, Ayyapan and Ramachandran (2011), Derbali (2011), Ali and Daly (2010). However, 
most of the studies has been done on conventional banking system without considering Islamic banking system. Therefore, due to this following gaps, this study seeks to provide the empirical evidence for both banking system.

A number of authors have considered the effect of inflation rate on NPLs. Previous studies from Mileris (2012) stated that increases in inflation rate had a positive effect to NPLs which mean, when the inflation rate is increasing, NPLs also increase. This finding were supported by Badar and Javid (2013), Bonilla (2012), Moinescu and Codirlasu (2012), Kochetkov (2012), Derbali (2011), Greenidge and Grosvenor (2010). On the other study by Warue (2013), the findings shows that inflation rate was negatively related to NPLs. The study employs both pooled (unbalanced and fixed effeck panel methods to investigate the effect of inflation rate on NPLs. It was supported by the previous study from Khemraj and Pasha (2009) and Kasselaki and Tagkalakis (2014). Therefore, in this study is concern more about the effect of inflation rate towards NPLs for both banking system.

Numerous studies have been done on the unemployment rate as one of the determinants of NPLs. From luga and Lazea (2012), they found that increasing in unemployment rate will cause an increasing in NPLs. This findings were supported by Klein (2013), Donath, Cerna and Oprea (2014) and Mileris (2014). Therefore, it is confirms that unemployment rate are positively related with NPLs.

\section{Implication of NPLs towads banking industry}

Most of the banks were experienced high Non-Performing Loans (NPLs). The earliest empirical studies on non-performing loans by Keeton and Morris (1987) founds that there are various factors leading to loan loss of 2,500 banks in USA. This is supported by Ahmad and Arif (2007) who agree that most banks in Nigeria and other countries such as Thailand, Indonesia, Malaysia, Japan and Mexico were experienced high NPLs and significant increase in credit risk during financial and banking crises. These were resulting several banks in Indonesia and Thailand was closing down. Although no bank was closed down in Malaysia, but the weaker banks were required to merge with others to reinforce their capital base which was eroded by massive accumulated losses due to impairment of loans.

For most banks, loans are the largest source of credit risk. According to Basel (2000), credit risk could be described as the potential that a bank debtor or counterparty will fail to meet commitments in accordance with agreed terms. Since credit risk is a major cause to the performance of the banks, therefore credit risk management could be the preventions to the failure of the banks. A study conducted by Hamisu (2011), found that credit risk management has a significant influence on the profitability of Nigeria banks. Therefore, the management of the banks needs to be cautious in setting up a credit policy that might not negatively affects profitability of the banks.

Knowing that loans is the largest of bank assets, therefore failure to manage loans would likely lead to high non-performing loans (Musau, 2014). According to Warue (2013), non-performing loans are positively related with bank landing rates in commercial banks. Ekanayake and Azeez (2015) indicated that NPLs tends to increase with weakening banks efficiency. Etale, Ayunku and Etale (2016) added that high level of NPLs would reduce the performance of the banks in the long run.

Karim, Chan and Hassan (2010) investigate the relationship between NPLs and bank efficiency as well as bank performance. The findings shows that the higher NPLs will reduce the bank performace. The most significant variables in their study is cost efficiency which mean, the lower cost efficiency will give the higher NPLs and hence the lower bank performance. It is supported by David, 
Nemwel and George (2014) and Chimkono and Njeru (2016), which the findings indicated that NPLS have negatively related to the bank performance.

\section{CONCEPTUAL FRAMEWORK AND RESEARCH METHODOLOGY}

The conceptual framework of research study is as shown in figure 2.

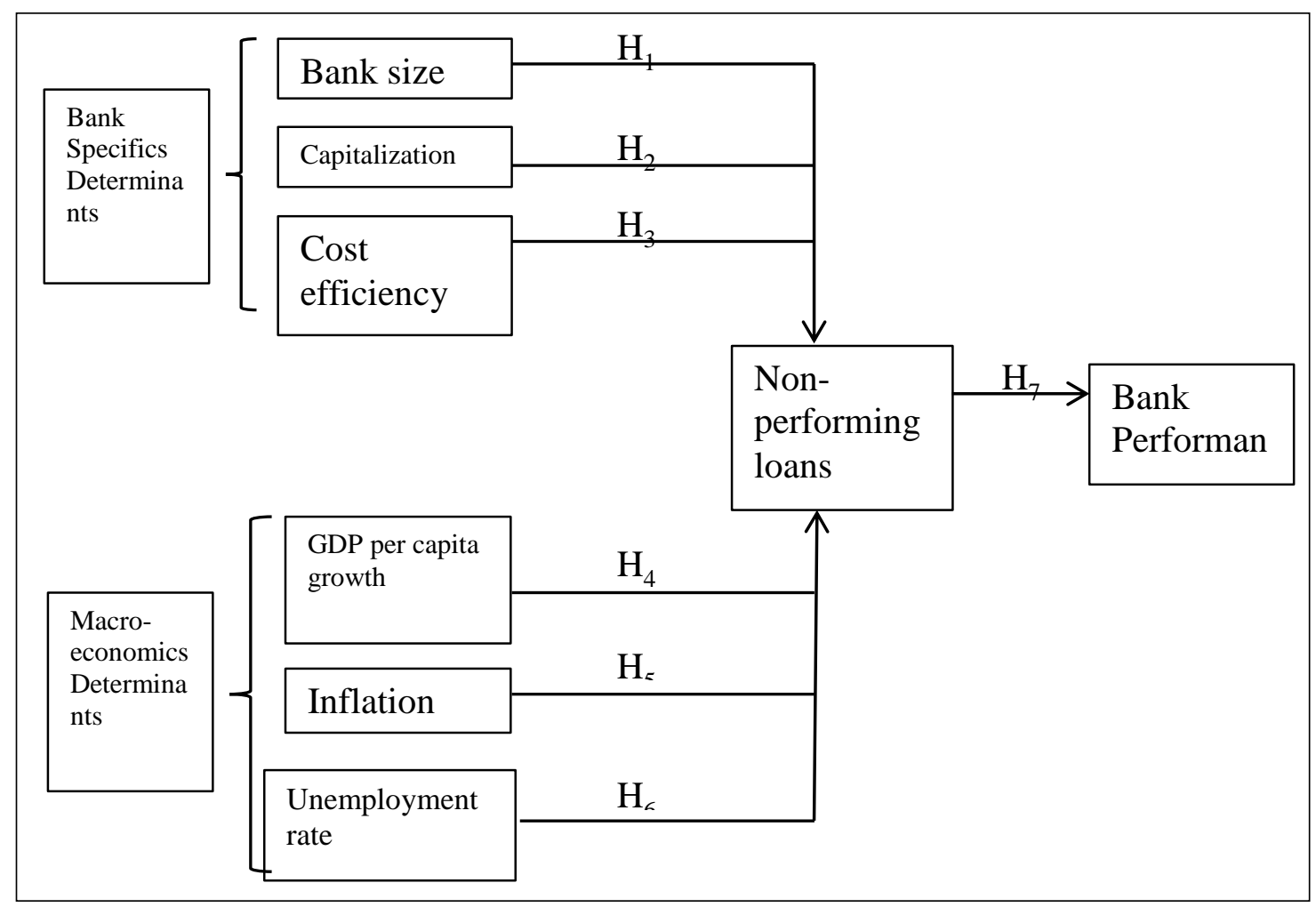

Figure 2: The Research Conceptual Framework

Dependent variable is the impact of the all the non-performing loans towards bank performance. Then independent variables are divided to two components, which are bank specific variables and macroeconomics for Islamic and conventional banking system.

\section{Research Hypotheses}

The study intended to see the relationship between the bank-specific and macroeconomics determinants towards NPL and hence the relationship between NPL and bank performance.

Frome the above conceptual framework, the following hypotheses were derived:

$$
\begin{aligned}
& \mathrm{H} 1(\mathrm{a}) /(\mathrm{b}) \text { : } \quad \text { Bank size has a significant effect towards non-performing loans specifically in } \\
& \text { Islamic banks/conventional banks } \\
& \mathrm{H} 2(\mathrm{a}) /(\mathrm{b}) \text { : } \quad \text { Capitalization has a significant effect towards non-performing } \\
& \text { loans specifically in Islamic banks/conventional banks } \\
& \mathrm{H} 3(\mathrm{a}) /(\mathrm{b}) \text { : Cost efficiency has a significant effect towards non-performing loans } \\
& \text { specifically in Islamic banks/conventional banks }
\end{aligned}
$$


INTERNATIONAL JOURNAL OF ACADEMIC RESEARCH IN BUSINESS AND SOCIAL SCIENCES Vol. 8, No. 12, Dec, 2018, E-ISSN: 2222-6990 @ 2018 HRMARS
H4(a)/(b): GDP growth rate has a significant effect towards non-performing loans specifically in Islamic banks/conventional banks
$\mathrm{H} 5(\mathrm{a}) /(\mathrm{b})$ : Inflation rate has a significant effect towards non-performing loans specifically in Islamic banks/conventional banks
$\mathrm{H6}(\mathrm{a}) /(\mathrm{b})$ : Unemployment rate has a significant positive effect towards non-performing loans specifically in Islamic banks/conventional banks
$\mathrm{H} 7(\mathrm{a}) /(\mathrm{b})$ : $\quad$ NPLs has a significant negative effect on bank performance specifically in Islamic banks/conventional banks

\section{Data Collection and sampling}

The population frame in this study consists of conventional and Islamic banks in ASEAN countries. This study will covers from small, medium and large banks, whether purely operate as Islamic banks or conventional banks in the ASEAN countries. This study will employ judgment-sampling technique to select required sample of banks. This sampling design is chosen in order to make sure all subgroups have sufficient elements and differentiated information is needed regarding various strata within the population. The required banks will be Islamic and conventional banks from Malaysia, Indonesia, Singapore, Thailand, Brunei and Philippines. These six countries already contributed more than 60 percent on gross domestic product for ASEAN.

\section{Data Analysis Method}

In estimating the factors affecting NPLs as wells its implications toward performance, researcher will employ Fixed Effect regression since this model allows control for heterogeneity across banks. The general forms of the model can be specified a follows:

$Y_{i t}=\alpha+\beta X_{i t}+\varepsilon_{i t}$

where the subscript $i$ denotes the cross-sectional dimension and $t$ represents the time-series dimension which is in year. $Y_{i t}$ represents the dependent variable, $X_{i t}$ denotes a set of independent variables in the model, $\alpha$ is a constant, $\beta$ represents the coefficients and $\varepsilon_{i t}$ represents the random error term.

\section{CONCLUSION}

This is a conceptual framework on a study to investigate the implications of NPLs toward bank performance. The conceptual framework and research hypotheses have been developed based on the review of the literature related to the bank performance and non-performing loans. Bycollecting data from various ASEAN countries, researcher aimed to model NPLs in a few Asian countries and later do a comparison across the model. With this discussion, by looking at the most influencing determinants or variables toward NPLs, it will provides important insights for the government as well as banking industry to find alternative solutions to make sure the percentage of the NPLs can be reduced for the years ahead. 
INTERNATIONAL JOURNAL OF ACADEMIC RESEARCH IN BUSINESS AND SOCIAL SCIENCES

Vol. 8, No. 12, Dec, 2018, E-ISSN: 2222-6990 @ 2018 HRMARS

\section{REFERENCES}

Abid, L., Ouertani, M. N., \& Zouari-Ghorbel, S. (2014). Macroeconomic and Bank-specific Determinants of Household's Non-performing Loans in Tunisia: A Dynamic Panel Data. Procedia Economics and Finance, 13, 58-68.

Agoraki, M. E. K., Delis, M. D., \& Pasiouras, F. (2011). Regulations, competition and bank risk-taking in transition countries. Journal of Financial Stability, 7(1), 38-48.

Ahmad, N. H., \& Ariff, M. (2007). Multi-Country Study of Bank Credit Risk Determinants. The International Journal of Banking and Finance, 5(1), 135-152.

Ali, A., \& Daly, K. (2010). Macroeconomic determinants of credit risk: Recent evidence from a cross country study. International Review of Financial Analysis, 19(3), 165-171.

Athanasoglou, P. P., Brissimis, S. N., \& Delis, M. D. (2008). Bank-specific, industry-specific and macroeconomic determinants of bank profitability. Journal of International Financial Markets, Institutions and Money, 18(2), 121-136.

Aziz, A., Farradila, N., \& Ibrahim, I. (2008). The impact of Non-performing Loans (NPL) towards profitability performance (ROA, ROE, \& NPM)/Nor Farradila Abdul Aziz, Irwan Ibrahim and Maizura Isa@Kamaruddin.

Badar, M., \& Yasmin Javid, A. (2013). Impact of macroeconomic forces on nonperforming loans: An empirical study of commercial banks in Pakistan. WSEAS Transactions on Business and Economics, 10(1), 40-48.

Basel (2000). Principles for the Management of Credit Risk. Basel Committee on Banking Supervision. Bank for International Settlements. Retrieved from: http://www.bis.org/publ/bcbs54.pdf.

Beck, R., Jakubik, P., \& Piloiu, A. (2013). Non-performing loans: What matters in addition to the economic cycle? European Central Bank Working Paper Series, (1515), 34.

Belaid, F. (2014). Loan quality determinants: evaluating the contribution of bank-specific variables, macroeconomic factors and firm level information (No. 04/2014). Graduate Institute of International and Development Studies Working Paper.

Berger, A. N., \& DeYoung, R. (1997). Problem loans and cost efficiency in commercial banks. Journal of Banking and Finance, 21(6), 849-870.

Bonilla, C. A. O. (2012). Macroeconomic determinants of the non-performing loans in Spain and Italy. Unpublished MSc Thesis, Leicester: University of Leicester.

Boudriga, A., Boulila, N., \& Jellouli, S. (2009). Does Bank Supervision Impact Nonperforming Loans : Cross-Country Determinants using Agregate Data. Munich Personal RePEc Archive, (18068), 128.

Chaibi, H. (2016). Determinants of Problem Loans: Non-performing Loans vs. Loan Quality Deterioration. International Business Research.

Chimkono, E. E., \& Muturi, W. (2016). Effect on non-performing loans and other factors on performance of commercial banks in Malawi. International Journal of Economics, Commerce and Management, IV(2), 549-563. http://doi.org/ISSN : 2348-0386

David, W., Nemwel, B., \& George, G. (2014). Impact of non-performing loans on financial performance of microfinance banks in Kenya. Int Researchernational Journal of Science and, 3(10), 2073-2078. http://doi.org/ISSN: 2319-7064 
Delis, M. D., \& Papanikolaou, N. I. (2009). Determinants of bank efficiency: evidence from a semiparametric methodology. Managerial Finance, 35(3), 260-275.

Derbali, A. (2011). Determinants of banking profitability before and during the financial crisis of 2007: The case of Tunisian banks.

Donath, L., Cerna, V. M., \& Oprea, I. M. (2014). Macroeconomic determinants of bad loans in Baltic countries and Romania. SEA - Practical Application of Science, II(4 (6)), 71-80.

Ekanayake, E. M. N. N., \& Azeez, A. A. (2015). Determinants of non-performing loans in licensed commercial banks: Evidence from Sri Lanka. Asian Economic and Financial Review, 5(6), 868.

Etale, L. M., Ayunku, P. E., \& Etale, E. (2016). The impact of Non-performing Loans and Bank Performance in Nigeria. International Journal of Humanities and Social Science Invention, 5(4), 1-5.

Fajar, H., \& Umanto. (2017). The impact of macroeconomic and bank-specific factors toward nonperforming loan: evidence from Indonesian public banks. Banks and Bank Systems.

Fofack, Hippolyte L.. 2005. Nonperforming loans in Sub-Saharan Africa : causal analysis and macroeconomic implications (English). Policy, Research working paper ; no. WPS 3769. Washington, DC: World Bank.

Geletta, W. N. (2012). Determinants of non-performing loans: The case of Ethiopian banks (Doctoral dissertation).

Greenidge, K., \& Grosvenor, T. (2010). FORECASTING NON-PERFORMING LOANS IN BARBADOS. Journal of Business, Finance \& Economics in Emerging Economies, 5(1).

Hamisu, S. K. (2011). Credit risk and the performance of Nigerian banks. Journal of Business Administration, 13(1).

luga, I., \& Lazea, R. (2012). Study Regarding the Influence of the Unemployment Rate over NonPerforming Loans in Romania Using the Correlation Indicator. Annales Universitatis Apulensis: Series Oeconomica, 14(2), 496.

Jiménez, G., \& Saurina, J. (2006). Credit Cycles, Credit Risk, and Prudential Regulation. International Journal of Central Banking, 2(January), 65-98.

Karim, M. Z. A., Chan, S. G., \& Hassan, S. (2010). Bank efficiency and non-performing loans: Evidence from Malaysia and Singapore. Prague Economic Papers, 2(2010), 118-132.

Kasselaki, M. T., \& Tagkalakis, A. O. (2014). Financial soundness indicators and financial crisis episodes. Annals of Finance, 10(4), 623-669.

Khemraj, T., \& Pasha, S. (2009). The determinants of non-performing loans: an econometric case study of Guyana.

Klein, N. (2013). Non-performing loans in CESEE: Determinants and impact on macroeconomic performance (No. 13-72). International Monetary Fund.

Kochetkov, Y. (2012). Modern model of interconnection of inflation and unemployment in Latvia. Engineering Economics, 23(2), 117-124.

Kwan, S., \& Eisenbeis, R. a. (1997). Bank Risk, Capitalization, and Operating Efficiency. Journal of Financial Services Research, 12(2-3), 117-131.

Laryea, E., Ntow-Gyamfi, M., \& Alu, A. A. (2016). Nonperforming loans and bank profitability: evidence from an emerging market. African Journal of Economic and Management Studies, $7(4), 462-481$. 
INTERNATIONAL JOURNAL OF ACADEMIC RESEARCH IN BUSINESS AND SOCIAL SCIENCES

Vol. 8, No. 12, Dec, 2018, E-ISSN: 2222-6990 @ 2018 HRMARS

Louzis, D. P., Vouldis, A. T., \& Metaxas, V. L. (2012). Macroeconomic and bank-specific determinants of non-performing loans in Greece: A comparative study of mortgage, business and consumer loan portfolios. Journal of Banking \& Finance, 36(4), 1012-1027.

Mileris, R. (2012). Macroeconomic determinants of loan portfolio credit risk in banks. Engineering Economics, 23(5), 496-504.

Misra, B. M., \& Dhal, S. (2010). Pro-cyclical management of banks' non-performing loans by the Indian public sector banks. BIS Asian Research Papers.

Moinescu, B., \& Codirlasu, A. (2012). Assessing the Sectoral Dynamics of Non-performing Loans: Signs from Financial and Real Economy. Theoretical \& Applied Economics, 19(2).

Musau, E. M. (2014). Modeling Non-performing Loans in Kenya Commercial Banks By Emmanuel Munyao Musau. Masters Thesis.

Mwega, F. (2011), The Competitiveness and Efficiency of the Financial Services Sector in Africa: A Case Study of Kenya. African Development Review, 23: 44-59.

Onsarigo, I. M., Selvan, M., Ramkumar, R. R. \& Karpagam, V. (2013). "Relative Efficiency of Kenyan Commercial Banks”, International Business Management. Vol. 7, No. 3, pp. $142-150$.

Peristiani, S. (1997). Do Mergers Improve the X-Efficiency and Scale Efficiency of U.S. Banks? Evidence from the 1980s. Journal of Money, Credit \& Banking (Ohio State University Press).

Podpiera, J., \& Weill, L. (2008). Bad luck or bad management? Emerging banking market experience. Journal of Financial Stability, 4(2), 135-148.

Rajan, R., Dhal, S.C. (2003). "Non-performing loans and terms of credit of public sector banks in India: An empirical assessment". Reserve Bank of India Occasional Papers, 24(3), pp 81-121.

Salas, V., \& Saurina, J. (2002). "Credit risk in two institutional regimes: Spanish commercial and savings banks". Journal of Financial Services Research, 22(3), 203-224.

Sheefeni, J. P. (2015). Evaluating the Impact of Bank Specific Determinants of Non-performing Loans in Namibia. Journal of Emerging Issues in Economics, Finance and Banking , Vol.4 (No.2), PP.1525-1541.

Thiagarajan, S., Ayyappan, S., \& Ramachandran, A. (2011). Credit Risk Determinants of Public and Private Sector Banks in India. European Journal of Economics, Finance and Administrative Sciences, 34(34), 147-153.

Warue, B. N. (2013). The effects of bank specific and macroeconomic factors on nonperforming loans in commercial banks in Kenya: A comparative panel data analysis. Advances in Management and Applied Economics, 3(2), 135.

Zurairah, I. (2010). Determinants of The Non-performing Loans of Comercial Banking Institutions in Malaysia, (June). Masters thesis, Universiti Sains Malaysia. 